\title{
Distribution of Mycobacterium tuberculosis lineages in South America
}

\section{Distribución de los linajes de Mycobacterium tuberculosis en Sudamérica}

\author{
Leslie Cabezas Vinueza. ${ }^{1}$. \& Patricia Jiménez Arias. ${ }^{2}$
}

\section{DOI: https://doi.org/10.33262/anatomiadigital.v4i3.1755}

\begin{abstract}
.
Molecular genotyping of Mycobacterium tuberculosis allows for the identification of circulating lineages and sublineages in the population and their relationship with migratory movements. The purpose of this review is to describe the phylogeography of Mycobacterium tuberculosis reported in South American countries that was analyzed using genotyping tools, analyze the Tuberculosis hotspots for the region and determine the impact of the COVID-19 pandemic on the Tuberculosis control program. The Latin American Mediterranean (LAM) sublineage
\end{abstract}

\section{Resumen.}

La genotipificación molecular de Mycobacterium tuberculosis permite identificar los linajes y sublinajes circulantes en la población y su relación con los movimientos migratorios. Este artículo de revisión tiene por objetivo describir la filogeografía de Mycobacterium tuberculosis reportada por los países de Sudamérica mediante el uso de técnicas de genotipificación, analizar los puntos críticos de Tuberculosis para la región y determinar el impacto de la pandemia de COVID-19 en el programa de control de la

\footnotetext{
${ }^{1}$ Grupo de Investigación en Sanidad Animal y Humana, Carrera de Ingeniería en Biotecnología, Departamento de Ciencias de la Vida y de la Agricultura, Universidad de las Fuerzas Armadas ESPE, Sangolquí, Ecuador, lpcabezas1 @espe.edu.ec. (iD https://orcid.org/0000-0003-1742-2878

${ }^{2}$ Grupo de Investigación en Sanidad Animal y Humana, Carrera de Ingeniería en Biotecnología, Departamento de Ciencias de la Vida y de la Agricultura, Universidad de las Fuerzas Armadas ESPE,

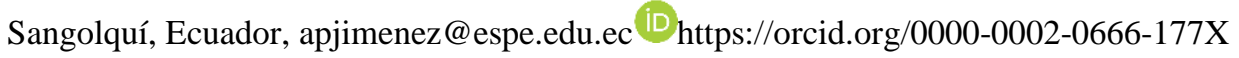


belonging to the Euro-American lineage (Lineage 4) presents the highest prevalence in South America and is followed by the Beijing sublineage belonging to the East Asian lineage (Lineage 2). The Beijing sublineage is considered of worldwide interest because of its association with multidrugresistant tuberculosis (MDR-TB), which is almost entirely distributed in South America, with Peru being the country with the highest prevalence for this sublineage. On the other hand, the IndoOceanic (Lineage 1), India-East Asia (Lineage 3) and West- African 2 (Lineage 6) sublineages have been reported with lower prevalence in South America. The molecular techniques used in the genotyping studies for Mycobacterium tuberculosis in South America were as follows: typing by complementary oligonucleotide spacer sequences (Spoligotyping), restrictionhybridization patterns (IS6110-RFLP, PGRS-RFLP), mycobacterial interspaced repeat units-variable number tandem repeats (MIRU-VNTR) and whole genome sequencing (WGS). At present, Brazil and Peru are the hotspots for tuberculosis and MDR-TB in South America, where the control of tuberculosis wholly affected by the COVID-19 pandemic. Thus, there have been significant impacts on containment programs and possible post-pandemic scenarios such that scientific contributions will need to be evaluated and implemented with new strategies for prevention, diagnosis, treatment and control of Tuberculosis.

Keywords: Molecular epidemiology; genotyping; Tuberculosis; infectious diseases; mycobacteria.
Tuberculosis. El linaje Latin American Mediterranean (LAM) perteneciente al linaje Euro-Americano (linaje 4) presenta la mayor prevalencia en Sudamérica y le sigue el sublinaje Beijing, perteneciente al linaje Asia oriental (linaje 2). El sublinaje Beijing considerado de interés mundial por su asociación con la Tuberculosis multirresistente (MDR-TB), se encuentra distribuido casi en su totalidad en Sudamérica, siendo Perú el país con mayor prevalencia de este sublinaje. Por otro lado, se han reportado los sublinajes pertenecientes a: IndoOceánico (Linaje 1), India-Asia Oriental (Linaje 3) y África Occidental 2 (Linaje 6) con menor prevalencia en Sudamérica. En la actualidad, Brasil y Perú son los puntos calientes de la Tuberculosis y la TB-MDR en Sudamérica, donde el control de la Tuberculosis se vio totalmente afectado por la pandemia de COVID-19. Por lo tanto, ha habido impactos significativos en los programas de vigilancia y contención de la Tuberculosis, dando como resultado diferentes escenarios post-pandémicos, de tal manera que las contribuciones científicas deberán ser evaluadas e implementadas con nuevas estrategias de prevención, diagnóstico, tratamiento $\mathrm{y}$ control de la Tuberculosis.

Palabras claves: Epidemiología molecular, genotipificación; Tuberculosis; enfermedades infecciosas; micobacterias. 


\section{Introduction.}

Tuberculosis (TB) is a preventable, transmissible bacterial disease caused by Mycobacterium tuberculosis (Koch bacillus) and is one of the top 10 causes of death worldwide from an infectious agent. This bacterial infection is cataloged as a health problem in both the social and health fields, is associated with poor living conditions and causes the death of 1.3 million people worldwide per year, which is 300,000 more than the human immunodeficiency virus (HIV) (World Health Organization, 2020). The World Health Organization (WHO) has developed a global strategy to end the TB epidemic and has set targets to reduce TB deaths and incidence of the disease by 2035 by combining efforts to provide timely diagnosis and treatment and to promote research (García \& Astudillo, 2019; PAHO, 2020).

In 2018, in the American region, it was estimated that almost 50,000 people with TB were unaware of their disease (PAHO, 2018). This region has $2.9 \%$ of the global TB burden (10 million cases) and an incidence rate of 10 per 100,000 inhabitants (World Health Organization, 2020). It was estimated that $87 \%$ of TB cases are concentrated in Brazil, Peru, Mexico, Haiti, Colombia, Venezuela, Argentina, Bolivia, the United States, El Salvador, Panama and Guyana (PAHO, 2020).

There are 7 Mycobacterium tuberculosis (MTB) lineages that are distributed worldwide, and they divided into two ancestral and modern groups, with the ancestral lineages being Lineage 1 (Indo-Oceanic), Lineage 5 (West African 1) and Lineage 6 (West African 2), while the modern lineages are Lineage 2 (East Asia), Lineage 3 (India-East Asia), Lineage 4 (Euro-American) and Lineage 7 (Ethiopia). Lineage 7 represents an intermediate phylogenetic branch between the ancestral and modern lineages. Lineages 5 and 6 correspond to strains traditionally known as Mycobacterium africanum, and lineages 2 and 4 are more virulent and prevalent worldwide. There are 16 sublineages, and the most important ones are as follows: lineage 1, MANU and EAI; lineage 2, Beijing; lineage 3, Central Asian (CAS) and Delhi; lineage 4, Haarlem (H), Latin American Mediterranean (LAM), T, X, S, Ghana, URAL, TUR, Uganda and H37Rv; and lineage 6, AFRI and West African (Augusto et al., 2018; Salvato et al., 2019).

This review describes the phylogeography of MTB sublineages reported in South American countries that was analyzed using genotyping tools, analyzes the TB hotspots in South America, and determines the impact of COVID-19 on TB control strategies.

\section{The molecular epidemiology techniques}

The molecular epidemiology of MTB aims, by a comparative analysis of nucleic acid sequences of strains to determine the relationship when the stains descend from a common ancestor and where the level of closeness and similarity between isolates varies. Molecular markers allow for the determination of the level of genetic relationship between strains according to variations in the DNA sequence due to single nucleotide polymorphisms (SNPs), long sequence polymorphisms (LSPs), or repeated sequence polymorphisms; this method allows for the characterization of the lineages of strains as 
phylogenetic contributions to control the disease and disrupt the transmission chain (Coll \& García de Viedma, 2018).

The techniques used for genotyping are typing by complementary oligonucleotide spacer sequences (spoligotyping), restriction-hybridization patterns (IS6110-RFLP, PGRSRFLP), mycobacterial interleaved repeat units-variable number tandem repeats (MIRUVNTR), and whole genome sequencing (WGS). The most advanced technique in the analysis of MTB from clinical samples is WGS, which allows the study of genome microevolution and the preparation of genomic libraries to identify epidemiological events of interest, with greater discrimination when detecting outbreaks, virulence, pathogenesis, transmission chains and mutations associated with resistance to first- and second- line antituberculosis drugs (Guthrie et al., 2019; Meehan et al., 2019). MIRUVNTR is also a highly stable, fast, reproducible and highly discriminatory technique, which is why it is considered for epidemiological studies, population genetics and phylogenetic studies of pathogens belonging to the Mycobacterium tuberculosis complex (MTBC) (Babai Kochkaksaraei et al., 2019; Jiménez et al., 2017). These two molecular techniques are the most widely used for studying the genotyping of MTB, and MIRUVNTR is used more often in developing countries of South America than WGS.

\section{Description of the circulating lineages in South America}

The molecular epidemiological analysis is stratified by country through the molecular characterization of MTB and allows us to know the dynamics of disease transmission and to identify high-risk groups in order to provide an early response to outbreaks. In this way, several studies in South America report the circulating sublineages in each country and their percentage of prevalence is of interest for the control of TB in South America (Hill et al., 2020).

\section{Brazil}

It is the country with the highest number of TB cases and the second highest concentration of rifampicin- and multidrug-resistant tuberculosis (RR/MDR-TB) in the American region. In 2019, 76,000 new cases of TB were reported, and nearly 4,500 deaths occurred. Most of the cases reported in this country were concentrated in the southeast, where the state of São Paulo (SP) represented $20 \%$ of the disease incidence in the country. As one of the countries with the largest geographical extension in South America and having several borders, Brazil has a great variety of circulating lineages of MTB. There are foreign MTB lineages due to the movement of the population for tourism and commercial events. Currently, TB transmission routes are present in both rural and urban populations, so special attention has been given to study the disease through molecular epidemiology techniques, early diagnosis, and monitored treatment. The HIV-infected population and people deprived of their liberty are vulnerable groups, so plans for diagnosis and observed treatment have been implemented to disrupt the chain of transmission (Esteves et al., 2018; PAHO, 2020) 
The circulating sublineages in Brazil with the highest percentages of prevalence are LAM (48.87\%), RD Rio (22.58\%), Haarlem (13.7\%), T (16.5\%), X (3.6\%), and S (2.05\%), belonging to lineage 4 , which prevails in the American region, due to the stability of its genotype and transmissibility. The lineages with the lowest prevalence are: Beijing $(0.65 \%)$, Uganda $(0.65 \%)$, MANU $(0.58 \%)$, EAI $(0.48 \%)$, CAS $(0.45 \%)$, West African $(0.26 \%)$, H37Rv (0.24\%), Ural (0.13\%), Cameroon (0.065\%), BOV (0.02\%) and Ghana $(0.02 \%)$ (Table 1$)$. The lineages 3, 4 and 6 have been incorporated into a variety of MTB lineages found in Brazil by the migration of people (Esteves et al., 2018; Salvato et al., 2019). Brazil has a low incidence of unidentified strains $(10.5 \%)$, which is due to the implementation of molecular techniques such as spoligotyping, MIRU-VNTR (24 and 12 loci) and WGS to determine the transmission routes of TB (Cardoso Oelemann et al., 2011; Dalla Costa et al., 2013; Gomes et al., 2012; Luiz et al., 2013; Machado et al., 2014; Martins et al., 2013; Medeiros et al., 2018; Nogueira et al., 2016; Noguti et al., 2010; Soares et al., 2013; Vasconcellos et al., 2014).

In 2007, MTB isolates from Rio de Janeiro were analyzed for genomic deletions. The $\mathrm{RD}^{\text {Rio }}$ sublineage was characterized as having a new deletion of a single long-sequence polymorphism (> $26.3 \mathrm{~kb}$ ) that included 10 genes. This sublineage was derived from a common ancestor that belongs only to the LAM sublineage, and is thus a predominant clade that causes TB in Rio de Janeiro and the most important source of recent transmission. ${ }^{37}$ The clinical picture of people infected with MTB $\mathrm{RD}^{\text {Rio }}$ presents a predisposition to resistance to multiple drugs, hemoptysis (coughing up blood), weight loss, and association with higher bacillary loads (Esteves et al., 2018; Lazzarini et al., 2007).

\section{Peru}

After Brazil, Peru is the country with the second highest concentration of TB cases and the first in terms of RR/MDR-TB cases in the American region. In 2018, 31,668 TB cases were reported of which 1,457 corresponded to RR/MDR-TB and 121 to extremely resistant TB (XDR-TB). Metropolitan Lima and Callao account for $64 \%$ of TB cases in this country. Some indicators show progress in disease control, such as decreases of $2 \%$ and $3 \%$ per year for the reported incidence and total morbidity rates; however, the numbers of XDR-TB cases have increased (Centro de Epidemiología, Prevención y Control de \& enfermedades, 2019; PAHO, 2020; Soto Cabezas et al., 2020). Peru, because of its political and geographical history, has had visitation of different nationalities that have increased the variety of MTB lineages in this region. Among the visitors are persons from Asia, a continent with a high incidence of TB worldwide and with the presence of lineages with high virulence and pathogenicity, such as Beijing (Farhat et al., 2019).

The most prevalent sublineages in Peru are LAM (35\%), Haarlem (31\%), and Beijing (10.27\%); these findings are consistent with the data for the incidence of MDR/XDR-TB cases, since the Beijing sublineage is associated with cases of resistance to both first- and second-line anti-tuberculosis drugs. In several studies, the Haarlem sublineage had the 
highest incidence rates due to the stability of this genotype in the population and the high rate of recent transmission. The sublineages with the lowest prevalence in Peru are $\mathrm{X}$ (3.1\%), T (7.4\%), S (0.32\%), U (0.32\%), MANU (0.01\%), Ghana (0.01\%), and EAI $(0.01 \%)$; the presence of these sublineages correlates with the movement of people from the Asian region (Table 1). The percentage of unidentified strains $(12.2 \%)$ is relatively low due to the implementation of molecular techniques such as spoligotyping, MIRUVNTR (24 and 12 loci), and WGS to determine the transmission routes of TB (Barletta et al., 2013, 2015; Cáceres et al., 2014; Cohen et al., 2011; Farhat et al., 2019; Grandjean et al., 2015, 2017; Huang et al., 2020; Sheen et al., 2013; Taype et al., 2012).

\section{Colombia}

In the American region, Colombia has the fifth-highest concentration of TB cases after Mexico and Haiti and the sixth-highest concentration of RR/MDR-TB cases (PAHO, 2020). In 2019, there were 14,684 cases of TB. The territorial entities with the highest rate are Amazonas, Guainía, Risaralda, Barranquilla, Meta, Arauca, and Casanare. TB is concentrated in the most vulnerable segments of the Colombian population, such as HIV patients $(11 \%)$, indigenous people $(5 \%)$, street dwellers $(4 \%)$, and prisoners $(6 \%)$ (Instituto Nacional de Salud de Colombia, 2020).

The most prevalent sublineages in Colombia are LAM (39.14\%), Haarlem (27.48\%), T (10.41\%), U (4.2\%), S (1.9\%), X (1.7\%), and Beijing (1.63\%); the lineage with the highest prevalence is LAM due to the stability of this genotype and transmissibility. The Beijing sublineage has a relatively low but persistent percentage in vulnerable populations such as the indigenous community and persons deprived of liberty (PPL). The sublineages with the lowest prevalence are MANU (0.2\%), EAI (0.1\%), Cameroon $(0.05 \%)$, CAS $(0.05 \%), \mathrm{H} 37 \mathrm{Rv}(0.05 \%)$, and West African (0.05\%); sublineages belonging to lineages 3, 4 and 6 have increased the variability of MTB genotypes (Table 1) (García \& Astudillo, 2019). The prevalence of unidentified strains is $7.4 \%$, one of the lowest in the region, due to the use of molecular techniques such as spoligotyping, MIRUVNTR (24 and 12 loci) and WGS for disease control (Beltrán-León et al., 2020; Castro et al., 2017; Cerezo et al., 2012; Cubillos-Ruiz et al., 2010; Guerra et al., 2019; D. Puerto et al., 2019; G. Puerto et al., 2015; Realpe et al., 2014).

\section{Venezuela}

It is the country with the sixth highest number of $\mathrm{TB}$ cases and with the eighth highest concentration of RR/MDR-TB in the American region (PAHO, 2020). In 2019, a TB infection rate of 47.8 per 100,000 people was reported (World Health Organization, 2020). In 2017, 10,952 cases of TB were reported (PAHO, 2018).

The most prevalent lineages in Venezuela are LAM (54.06\%), T (11.11\%), and Haarlem (4.72\%), belonging to lineage 4 , and those lineages with the lowest prevalence are $\mathrm{X}$ (1.25\%), Beijing $(0.41 \%)$, EAI $(0.35 \%)$ and MANU $(0.07 \%)$; there is evidence of lineages that are typical of the Asian region, which shows population movement. The $\mathrm{RD}^{\mathrm{Rio}}$ lineage $(55 \%)$, which is part of the LAM lineage, has a relatively high prevalence 
(Table 1$)$. The unidentified strains $(0.83 \%)$ show a percentage close to zero due to the application of highly discriminatory molecular techniques such as MIRU-VNTR 24-loci (Abadía et al., 2009; Maes et al., 2008).

\section{Argentina}

It is the country with the seventh highest number of TB cases and with the seventh with the highest concentration of RR/MDR-TB in the American region (PAHO, 2020). In 2018, 11,670 cases of TB were reported, and 720 deaths occurred. Buenos Aires and Greater Buenos Aires had $45 \%$ of the cases at the country level, the incidence rate was 26.2 per 100,000 inhabitants, of which 6 out of 10 were men (Ministerio de Salud Argentina, 2020).

The sublineages with the highest prevalence are those belonging to lineage 4: $\mathrm{T}(31.55 \%)$, LAM (30.9\%), and Haarlem (18.4\%), with the T sublineage being the one with the highest concentration both in Buenos Aires and in Greater Buenos Aires due to its adaptability in the urban population. The sublineages with the lowest prevalence are $\mathrm{S}(2.19 \%), \mathrm{X}$ $(1.02 \%)$, and Beijing $(0.23 \%)$, belonging to lineages 2 and 4 . The $\mathrm{RD}^{\text {Rio }}$ sublineage (11.3\%), part of the LAM sublineage, has been reported as a foreign sublineage implemented by population movement between Argentina and Brazil (Table 1). Unidentified strains $(14.6 \%)$ present a relatively low percentage due to the use of molecular techniques such as spoligotyping, RFLP, and MIRU-VNTR 24-loci. The number of migrants from Europe and the Middle East has contributed to the diverse phylogeography of MTB (B. R. Imperiale et al., 2013; Belén Rocío Imperiale et al., 2019; Monteserin et al., 2018).

\section{Bolivia}

It is the country with the eighth highest number of TB cases and with the ninth highest concentration of RR/MDR-TB in the American region (PAHO, 2020). In 2018, 7,762 cases of TB were reported, where the Department of Santa Cruz had the highest incidence of TB in the country (42\%), with 3,240 cases and 103 deaths (PAHO/WHO, 2019a).

The most prevalent sublineages are Haarlem (39.4\%), LAM (26.3\%), and T (22\%), belonging to lineage 4 . The Haarlem sublineage presents high transmissibility and stability in rural geographic areas, which justifies its high prevalence. The identified sublineages with lower prevalence are S $(2 \%)$ and X (1\%), belonging to lineage 4 (Table 1). This study used spoligotyping and MIRU-VNTR (Monteserin et al., 2013).

\section{Guyana}

Guyana has the twelfth highest concentrations of TB in the American region, after the Dominican Republic, El Salvador and Panama (PAHO, 2020). In 2017, an incidence of 109 cases per 100,000 people and $35.1 \%$ of patients with TB and HIV were reported. TB control still has some challenges in this nation, and one of the most critical being the HIV epidemic in the population. This epidemic has been identified as a major concern and 
underlying cause of the increase in both TB morbidity and mortality (PAHO/WHO, 2019b). In 2018, Guyana was reported to be the country with the highest number of TB deaths in the American region (PAHO, 2020).

The sublineages with the highest prevalence are T (72.62\%), EAI (10.8\%), and Beijing (1.09\%), with the $\mathrm{T}$ sublineage being the one found at higher concentrations due to its adaptability in the urban population (Table 1). Unidentified strains $(16.2 \%)$ were reported in the studies, and the molecular techniques of spolygotipyng and 15-loci-MIRU-VNTR were used (Millet et al., 2014; Streit et al., 2014).

\section{Ecuador}

In 2018, 6,094 cases of TB were reported, including 252 cases with RR/MDR-TB, 805 cases of TB in people with HIV, 637 cases of TB in people deprived of their liberty, and 154 cases of TB in children under 15. Men infected with TB are predominant, with a ratio of 2.40 men to women, and the most affected age group is 25-34 years old. The urban coast region has the highest concentration of TB (Ministerio de Salud Pública et al., 2019).

The most prevalent circulating sublineages are LAM (42.9\%), Haarlem (26\%), S (11.53\%), Ghana (7.12\%) and X (3.35\%). The Beijing sublineage is of phylogenetic interest due to its high virulence and pathogenicity has been found in this country with a prevalence of $1.69 \%$, which shows that the movement of people from frontier countries such as Peru has been able to migrate foreign lineages, increasing the transmission of TB. The sublineages with the lowest prevalence are Cameroon $(0.83 \%)$ and Delhi $(0.4 \%)$, which are sublineages belonging to lineages 3 and 4 (Table 1). The percentage of unidentified isolates $(5.87 \%)$ is a relatively low value due to the use of more sensitive and specific techniques such as MIRU-VNTR 24-loci and WGS (Garzon-Chavez et al., 2019, 2020; Jiménez et al., 2017; Zurita et al., 2019).

\section{Paraguay}

In 2018, a rate of 43 per 100000 individuals was reported for TB in Paraguay, with Asunción, Central, and Alto Paraná being the regions that comprised 54\% of the country's cases. The disease had a greater incidence among the indigenous population (16.4\%) and persons deprived of their liberty (14.4\%) (Ministerio de Salud Pública y Bienestar Social, 2019).

The most prevalent lineages are LAM (46.06\%), Haarlem (17.27\%), RD ${ }^{\text {Rio }}$ (11.3\%), T (10.9\%), and $\mathrm{S}(9.7 \%)$, belonging to lineage 4 . The $\mathrm{RD}^{\text {Rio }}$ lineage shows the migration of people between Brazil and Paraguay. The sublineages with the lowest prevalence are $\mathrm{X}$ $(1.51 \%)$ and Beijing (0.3\%) (Table 1). There has been only one MTB genotyping study in this country; the study reported a case of a foreign lineage belonging to lineage 2 (Beijing sublineage), which was isolated from a South Korean immigrant residing in 
Asunción. This study used spoligotyping, and to confirm the results obtained, the molecular techniques of RFLP and MIRU-VNTR were applied (Candia et al., 2007).

\section{Chile}

Very low rates of TB in Chile have been achieved after decades of sustained economic development-related decline and a robust and monitored National TB Program. In 2017, 2,740 cases of TB were reported. In 2018, the incidence rate was 14.7 cases per 100,000 people (Ministerio de Salud, 2018).

The most prevalent sublineages are LAM (39.4\%), T (33.77\%), Haarlem (13.6\%) and X (3.64\%), belonging to lineage 4 . The LAM lineage is more prevalent due to the stability and transmissibility of this genotype. The sublineages with the lowest prevalence are Beijing (0.99\%), S (0.3\%), Cameroon (0.16\%), and AFRI (0.16\%), belonging to lineages 2 and 4 (Table 1). The Beijing sublineage is of interest because of its high pathogenicity and virulence present in the urban population of Chile due to migration from Peru and Venezuela (Balcells et al., 2015; Lagos et al., 2016; Meza et al., 2014).

\section{Suriname}

In 2018, an incidence of TB of 38 cases per 100000 people and $4.7 \%$ of patients with TB and HIV was reported; in 2017, an incidence of 29 cases per 100000 people was reported, suggesting an increase in TB transmission in the country (Commiesie et al., 2019).

The sublineages with the highest prevalence are T (26.25\%), EAI (25\%), Beijing (4.3\%), and Haarlem (10.8\%), with the Beijing sublineage having the highest percentage among Guianas (Table 1). Unidentified strains (31.2\%) were reported in the studies using the molecular techniques of spolygotipyng and 15-loci-MIRU-VNTR (Millet et al., 2014; Streit et al., 2014).

\section{Uruguay}

In 2018, an incidence of 33 cases per 100000 people was reported (PAHO, 2020). This result is currently all the information that is available since no MTB molecular genotyping studies have been performed in this country.

\section{French Guyana}

French Guyana has the highest burden of TB among all French territories with a sharp increase in the incidence of TB in recent years to 9.5 cases per 100,000 people. TB is the fourth most frequent opportunistic infection among HIV patients in this country (Nacher et al., 2020).

The sublineages with the highest prevalence are T (32.6\%), LAM (23.3\%) and Haarlem (22.6\%), with the T sublineage having the highest concentration due to its adaptability in the urban population and the LAM sublineage being the main circulating sublineage in South America (Table 1). The prevalence of more sublineages is unknown due to a single 
genotyping study carried out in the French region, and the molecular technique used was spoligotyping (Guernier et al., 2008).

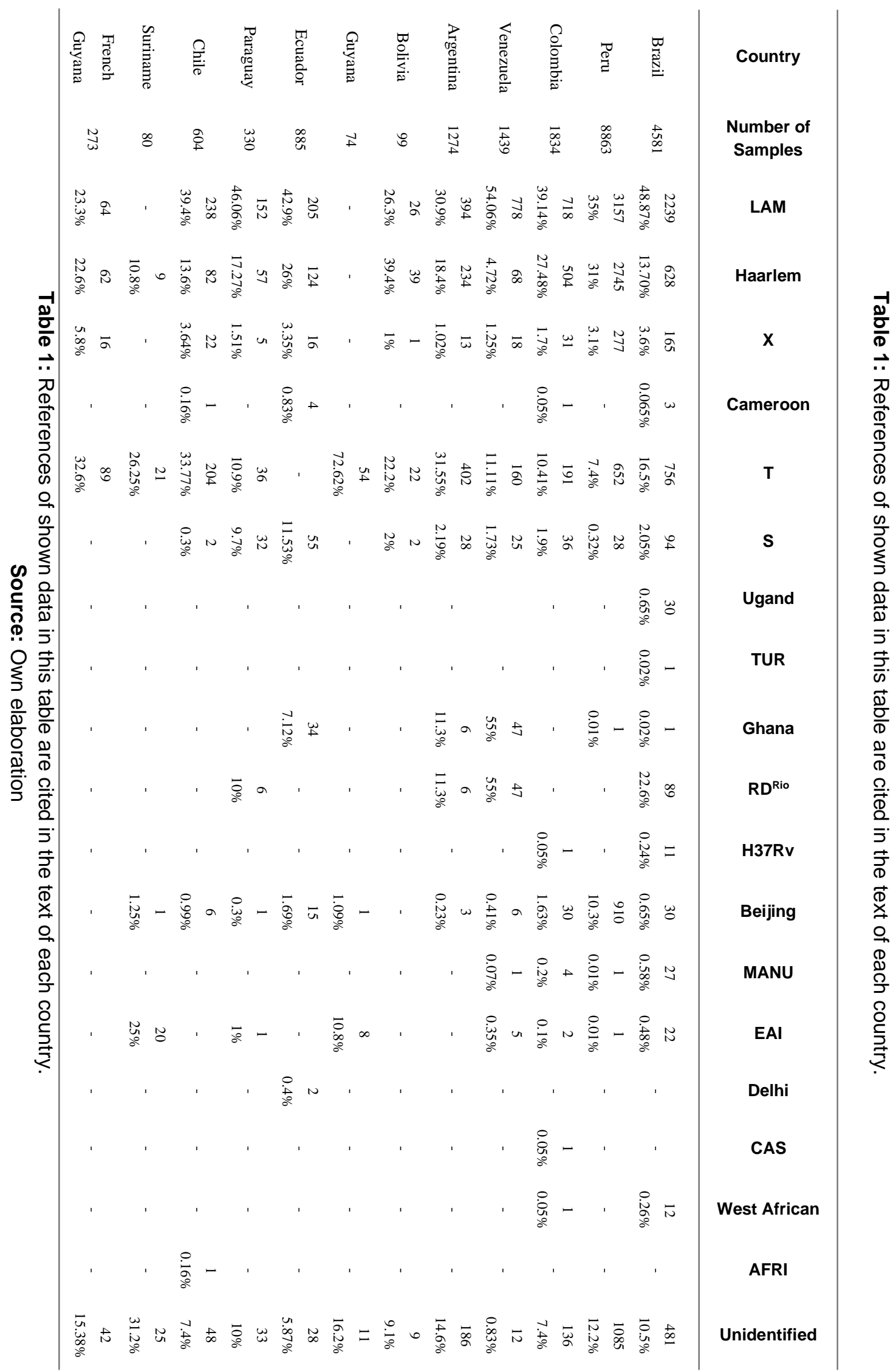


Molecular epidemiology studies in South America used to determine the lineages and sublineages circulating in each country, which the most prevalent are represented graphically according to their distribution and incidence rate of TB (Figure 1).

Distribution of the most prevalent MTB sublineages in South America.

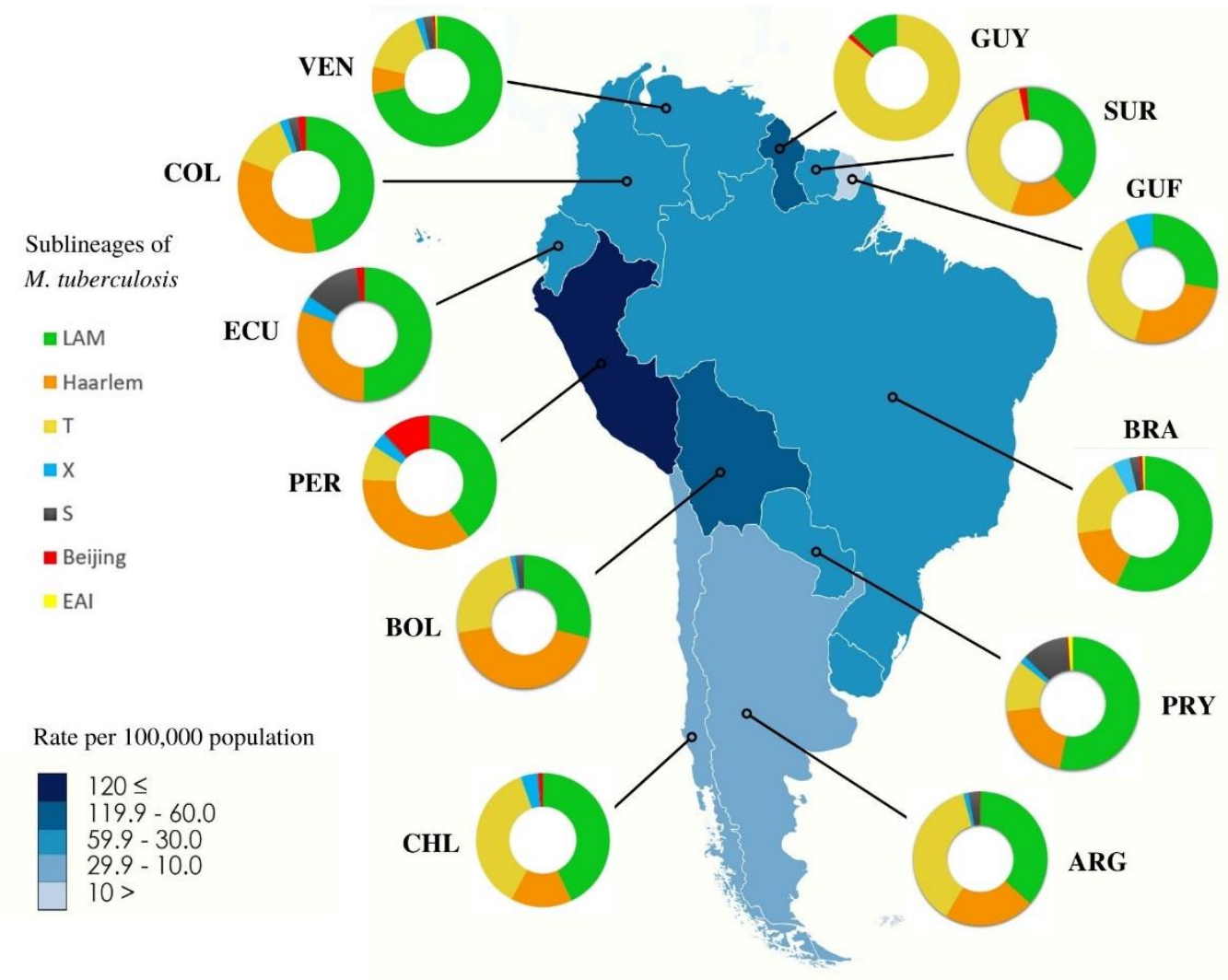

Figure 1: Data are included in Table 1 with de percentage of prevalence per country. Each country has been shaded according to the estimated TB incidence rate in concordance with the "Tuberculosis in the Americas 2019 regional report", by Pan American Health Organization (2020) [2]. Country codes (http://www.worldatlas.com/aatlas/ctycodes.htm).

Source: Own elaboration.

\section{The dynamics of lineage distribution in South America}

Susceptibility to MTB varies in every individual and this heterogeneity influences the routes and frequencies of transmission in a population. By understanding the magnitude and distribution of these differences, it is possible to predict the dynamics of the disease to control and reduce TB transmission (Rodrigues et al., 2017). The imminent interactions between host, environment and bacterial factors makes the epidemiological study of MTB difficult due to the independence of strains in phenotypic versus genotypic manifestation, explicitly in terms of virulence, where morbidity and mortality are the measures of proportion, since the virulence of MTB is directly related to transmission (Zhang et al., 2019).

Lineages 2, 3 and 4 are more transmissible than other lineages, and their sublineages are predisposed to adaptability to specific host populations; thus, their evolution has allowed 
them to be distributed worldwide (Zhang et al., 2019). In South America, these lineages are widely dispersed in both rural and urban areas, where factors such as air pollution, smoking, malnutrition, population density, crowded living conditions, HIV incidence and mobility among migrants increase TB transmission and distribution (Esteves et al., 2018). This dispersion is how the LAM sublineage appears in cities with high population concentrations, promoting a more severe disease due to its high mutation rate. In turn, a new mutation from this sublineage has been reported, giving rise to a new $\mathrm{RD}^{\text {Rio }}$ strain that appears in the population of Rio de Janeiro with a clinical picture that has with high bacillary loads (Moraes et al., 2017); lineage 4 sublineages such as Haarlem and T are directly related to their stability and transmissibility in urban areas and the $S$ sublineage in rural areas, especially in indigenous communities (Díaz Acosta et al., 2019; GarzonChavez et al., 2020). The Beijing sublineage is unique due to its high level of virulence, reduced inflammatory response and predisposition to antibiotic resistance. At present, its distribution in South America is not total, not because of its level of transmission and prevalence but because of the scarce genotyping studies in the countries where it is not reported (Cerezo-Cortés et al., 2019). For the circulating sublineages belonging to lineages 1, 3 and 6, since they have a low prevalence, it is not possible to determine their specific level of influence in a population area, except for their increased variability as complex outbreaks and new routes of infection (Garzon-Chavez et al., 2020).

\section{Brazil and Peru are hotspots for tuberculosis in South America}

Brazil is the country with the highest incidence of TB in South America, is an economic and tourism power, and has the greatest phylogenetic variety of MTB (lineages 1, 2, 3, 4 and 6). This diversity of lineages arises from the Portuguese impact on the country when it was a colony and the European and Asian impacts in the economic development of the country; thus, the most prevalent lineage is 4 , from which comes the $\mathrm{RD}^{\text {Rio }}$ sublineage that is currently found not only in the population of Rio de Janeiro but also in Paraguay, Argentina and Venezuela (Díaz Acosta et al., 2019; Esteves et al., 2018; Moraes et al., 2017; PAHO, 2020). The geographic extension of Brazil provides border proximity to almost all countries in South America, and thus, political and economic relations increase the movement of people and consequently the distribution of MTB. This phylogenetic diversity that Brazil brings to South America has led to complex outbreaks and new routes of infection to countries that do not have the molecular tools or control strategies to counteract the transmission of TB (Esteves et al., 2018; Medeiros et al., 2018; Rodrigues et al., 2017). It is worth mentioning that despite its population density and large geographic area, the presence of RR/MDR/XDR-TB is not reported as being critical as it is in Peru (Esteves et al., 2018).

Peru is the country with the second highest incidence of TB but the first in terms of RR/MDR-TB, which is related to the level of prevalence of the Beijing sublineage. Prevalence of the Beijing sublineage in Peru is the highest in South America (10.3\%) due to population migration from China associated with labor, commercial and economic factors. China is one of the hotspots with the highest level of TB prevalence in the world (Grandjean et al., 2017; Huang et al., 2020; PAHO, 2020). XDR-TB reports also have a 
higher incidence in this nation than in South America as a whole. The highest density of cases are concentrated in the districts of Lima and Callao and in more than half of the country's departments with high poverty rates (Grandjean et al., 2017; Soto Cabezas et al., 2020). Soto Cabezas et al., 2020 reported that almost half of the XDR-TB cases analyzed (48\%) had no previous anti-TB treatment, which highlights the need to evaluate TB control programs. For bordering countries, both Ecuador and Chile have reported an increase in Beijing sublineage strains, making Ecuador and Colombia additional areas identified as critical or hotspots for the prevalence of lineage 2 (Garzon-Chavez et al., 2020; Lagos et al., 2016).

\section{Impact of COVID-19 on TB disease}

It is likely that the high prevalence of TB and increasing COVID-19 allow a temporal association that has a synergistic effect both economically and socially, where comorbidity would increase the rate of deaths in both vulnerable individuals and the general population (Homolka et al., 2020). In 2020, there has been a significant decrease in presumptive, confirmed cases and notifications of TB deaths compared to 2019, which is associated with restricted access to the diagnostic testing and treatment centers during confinement and associated with the use of resources such as laboratories, people and supplies that are focused on emergency planning and containment of the COVID-19 pandemic (Buonsenso et al., 2021; Homolka et al., 2020).

One of the possible post-pandemic effects is the increase in morbidity and mortality from $\mathrm{TB}$ and RR/MDR/XDR-TB due to overcrowded conditions, treatment abandonment and lack of an active search for cases during confinement and outbreaks of COVID-19, allowing the appearance of new outbreaks and chains of transmission, especially in vulnerable populations; thus, measures should be taken and TB control programs should be evaluated and implemented (Buonsenso et al., 2021; Comella-del-Barrio et al., 2020). TB control requires surveillance interventions, clinical assessment, diagnostic testing, contact tracing, and confirmation of diagnosis with supervised treatment regimens; as all these important actions have been limited, all the recent advances in the End TB Strategy have been affected (Homolka et al., 2020; McQuaid et al., 2020; Motta et al., 2020). It is necessary to respond to the COVID-19 pandemic without neglecting an epidemic such as $\mathrm{TB}$, which is the fifth leading cause of death worldwide. This statement is even more true in South America where countries that are low development regions cannot cope with a coinfection of two infectious diseases or coinfection of up to three diseases if HIV is included.

\section{Conclusions.}

- The genotyping of MTB in the American region, mainly in South America, has provided results of epidemiological interest by identifying the circulating lineages that each country has and how migratory movements have contributed to the dissemination of TB and the increase in MTB genotypes in each country. 
- In this case, Brazil and Peru are the countries with the major incidences of TB and increased phylogenetic diversity of MTB in South America. According to the scientific reports analyzed in this review, a high prevalence of sublineages belonging to lineage 4 can be observed as LAM, Haarlem, Cameroon X, T, S, and Ghana. Additionally, the new sublineage $\mathrm{RD}^{\text {Rio }}$ has a more severe clinical profile and is currently found not only in Brazil, the country of origin, but also in Argentina, Venezuela and Paraguay. Another important prevalent sublineage is the Beijing, which belongs to lineage 2, and is dispersed throughout the countries of South America except Bolivia, Uruguay and French Guyana, where there are no reports of incidence thus far.

- The sublineages of lineages 1,3 and 6 have a low mutation rate, which correlates with their low transmissibility and adaptability in the population. MIRU-VNTR is highly discriminatory; however, there is still a low percentage of unidentified strains.

- Finally, the TB control directions are from the WHO, and each country implements these directions according to the country's resources (laboratories, supplies and people), which has been considered an impediment to harmonize strategies aimed at the control and elimination of the disease. Therefore, the response to the COVID-19 pandemic has a possible post-pandemic effect of a significant resurgence of TB cases; thus, as a scientific community, we must propose projects or seek diagnostic resources to actively search for cases, supervise and complete treatment, and epidemiologically control the disease and thereby disrupt the chain of transmission, especially in vulnerable populations.

\section{References.}

Abadía, E., Sequera, M., Ortega, D., Méndez, M. V., Escalona, A., Da Mata, O., Izarra, E., Rojas, Y., Jaspe, R., Motiwala, A. S., Alland, D., de Waard, J., \& Takiff, H. E. (2009). Mycobacterium tuberculosis ecology in Venezuela: Epidemiologic correlates of common spoligotypes and a large clonal cluster defined by MIRUVNTR-24. BMC Infectious Diseases, 9(122). https://doi.org/10.1186/1471-2334$9-122$

Augusto, C. J., Carvalho, W. da S., Almeida, I. N. de, Figueiredo, L. J. de A., Dantas, N. G. T., Suffys, P. N., \& Miranda, S. S. de. (2018). Comparative study of RFLPIS6110 and MIRU-VNTR from Mycobacterium tuberculosis isolated in the state of Minas Gerais, Brazil. Brazilian Journal of Microbiology: [Publication of the Brazilian Society for Microbiology], 49(3), 641-646. https://doi.org/10.1016/j.bjm.2017.04.015

Babai Kochkaksaraei, M., Kaboosi, H., \& Ghaemi, E. A. (2019). Reproducibility of 15Loci MIRU-VNTR Method in Mycobacterium tuberculosis Genotyping. Jundishapur Journal of Microbiology, 12(8), e86396. https://doi.org/10.5812/jjm.86396 
Balcells, M. E., García, P., Meza, P., Peña, C., Cifuentes, M., Couvin, D., \& Rastogi, N. (2015). A First Insight on the Population Structure of Mycobacterium tuberculosis Complex as Studied by Spoligotyping and MIRU-VNTRs in Santiago, Chile. PLOS ONE, 10(2), e0118007. https://doi.org/10.1371/journal.pone.0118007

Barletta, F., Otero, L., Collantes, J., Asto, B., de Jong, B. C., Seas, C., \& Rigouts, L. (2013). Genetic variability of Mycobacterium tuberculosis complex in patients with no known risk factors for MDR-TB in the North-Eastern part of Lima, Peru. BMC Infectious Diseases, 13(397). https://doi.org/10.1186/1471-2334-13-397

Barletta, F., Otero, L., de Jong, B. C., Iwamoto, T., Arikawa, K., Van der Stuyft, P., Niemann, S., Merker, M., Uwizeye, C., Seas, C., \& Rigouts, L. (2015). Predominant Mycobacterium tuberculosis Families and High Rates of Recent Transmission among New Cases Are Not Associated with Primary Multidrug Resistance in Lima, Peru. Journal of Clinical Microbiology, 53(6), 1854-1863. https://doi.org/10.1128/JCM.03585-14

Beltrán-León, M., Rodríguez-Castillo, J. G., Zozio, T., Rastogi, N., \& I Murcia, M. (2020). Genetic diversity of Mycobacterium tuberculosis clinical isolates from HIV-TB patients from two public hospitals at Bogotá, Colombia. Infection, Genetics and Evolution: Journal of Molecular Epidemiology and Evolutionary $\begin{array}{llll}\text { Genetics in Infectious } 104059 . & \text { Diseases, }\end{array}$ https://doi.org/10.1016/j.meegid.2019.104059

Buonsenso, D., Iodice, F., Sorba Biala, J., \& Goletti, D. (2021). COVID-19 effects on tuberculosis care in Sierra Leone. Pulmonology, 27(1), 67-69. https://doi.org/10.1016/j.pulmoe.2020.05.013

Cáceres, O., Rastogi, N., Bartra, C., Couvin, D., Galarza, M., Asencios, L., \& MendozaTicona, A. (2014). Characterization of the Genetic Diversity of Extensively-Drug Resistant Mycobacterium tuberculosis Clinical Isolates from Pulmonary Tuberculosis Patients in Peru. PLOS ONE, 9(12), e112789. https://doi.org/10.1371/journal.pone.0112789

Candia, N., Lopez, B., Zozio, T., Carrivale, M., Diaz, C., Russomando, G., de Romero, N. J., Jara, J. C., Barrera, L., Rastogi, N., \& Ritacco, V. (2007). First insight into Mycobacterium tuberculosis genetic diversity in Paraguay. BMC Microbiology, 7(1), 75. https://doi.org/10.1186/1471-2180-7-75

Cardoso Oelemann, M., Gomes, H. M., Willery, E., Possuelo, L., Batista Lima, K. V., Allix-Béguec, C., Locht, C., Goguet de la Salmonière, Y.-O. L., Gutierrez, M. C., Suffys, P., \& Supply, P. (2011). The forest behind the tree: Phylogenetic exploration of a dominant Mycobacterium tuberculosis strain lineage from a high tuberculosis burden country. PloS One, 6(3), e18256. https://doi.org/10.1371/journal.pone.0018256 
Castro, C., Ricardo, A., Zabaleta, A., Llerena, C., Puerto, G., Castro, C., Ricardo, A., Zabaleta, A., Llerena, C., \& Puerto, G. (2017). Characterization of clinical isolates of Mycobacterium tuberculosis from HIV positive individuals in Colombia, 2012. Biomédica, 37(1), 86-95. https://doi.org/10.7705/biomedica.v37i1.3112

Centro de Epidemiología, Prevención y Control de \& enfermedades. (2019). Sala situacional de Tuberculosis en el Perú. https://www.dge.gob.pe/portal/docs/tools/teleconferencia/2019/SE122019/04.pd $\mathrm{f}$

Cerezo, I., Jiménez, Y., Hernandez, J., Zozio, T., Murcia, M. I., \& Rastogi, N. (2012). A first insight on the population structure of Mycobacterium tuberculosis complex as studied by spoligotyping and MIRU-VNTRs in Bogotá, Colombia. Infection, Genetics and Evolution: Journal of Molecular Epidemiology and Evolutionary Genetics in Infectious Diseases, 12(4), 657-663. https://doi.org/10.1016/j.meegid.2011.07.006

Cerezo-Cortés, M. I., Rodríguez-Castillo, J. G., Hernández-Pando, R., \& Murcia, M. I. (2019). Circulation of M. tuberculosis Beijing genotype in Latin America and the Caribbean. Pathogens and Global Health, 113(8), 336-351. https://doi.org/10.1080/20477724.2019.1710066

Cohen, T., Murray, M., Abubakar, I., Zhang, Z., Sloutsky, A., Arteaga, F., Chalco, K., Franke, M. F., \& Becerra, M. C. (2011). Multiple Introductions of MultidrugResistant Tuberculosis into Households, Lima, Peru. Emerging Infectious Diseases, 17(6), 969-975. https://doi.org/10.3201/eid1706.101471

Coll, P., \& García de Viedma, D. (2018). Molecular epidemiology of tuberculosis. Enfermedades Infecciosas y Microbiología Clínica (English Edition), 36(4), 233240. https://doi.org/10.1016/j.eimce.2018.01.001

Comella-del-Barrio, P., De Souza-Galvão, M. L., Prat-Aymerich, C., \& Domínguez, J. (2020). Impact of COVID-19 on Tuberculosis Control. Archivos de Bronconeumología. https://doi.org/10.1016/j.arbres.2020.11.016

Commiesie, E., Stijnberg, D., Marín, D., Perez, F., \& Sanchez, M. (2019). Determinants of sputum smear nonconversion in smear-positive pulmonary tuberculosis patients in Suriname, 2010 - 2015. Revista Panamericana de Salud Pública, 43. https://doi.org/10.26633/RPSP.2019.86

Cubillos-Ruiz, A., Sandoval, A., Ritacco, V., López, B., Robledo, J., Correa, N., Hernandez-Neuta, I., Zambrano, M. M., \& Del Portillo, P. (2010). Genomic signatures of the haarlem lineage of Mycobacterium tuberculosis: Implications of strain genetic variation in drug and vaccine development. Journal of Clinical Microbiology, 48(10), 3614-3623. https://doi.org/10.1128/JCM.00157-10 
Dalla Costa, E. R., Lazzarini, L. C. O., Perizzolo, P. F., Díaz, C. A., Spies, F. S., Costa, L. L., Ribeiro, A. W., Barroco, C., Schuh, S. J., da Silva Pereira, M. A., Dias, C. F., Gomes, H. M., Unis, G., Zaha, A., Almeida da Silva, P. E., Suffys, P. N., \& Rossetti, M. L. R. (2013). Mycobacterium tuberculosis of the RDRio genotype is the predominant cause of tuberculosis and associated with multidrug resistance in Porto Alegre City, South Brazil. Journal of Clinical Microbiology, 51(4), 10711077. https://doi.org/10.1128/JCM.01511-12

Díaz Acosta, C. C., Russomando, G., Candia, N., Ritacco, V., Vasconcellos, S. E. G., de Berrêdo Pinho Moreira, M., de Romero, N. J., Morcillo, N., De Waard, J. H., Gomes, H. M., \& Suffys, P. N. (2019). Exploring the "Latin American Mediterranean" family and the RDRio lineage in Mycobacterium tuberculosis isolates from Paraguay, Argentina and Venezuela. BMC Microbiology, 19(1), 131. https://doi.org/10.1186/s12866-019-1479-6

Esteves, L. S., Dalla Costa, E. R., Vasconcellos, S. E. G., Vargas, A., Ferreira Junior, S. L. M., Halon, M. L., Ribeiro, M. O., Rodenbusch, R., Gomes, H. M., Suffys, P. N., \& Rossetti, M. L. R. (2018). Genetic diversity of Mycobacterium tuberculosis isoniazid monoresistant and multidrug-resistant in Rio Grande do Sul, a tuberculosis high-burden state in Brazil. Tuberculosis (Edinburgh, Scotland), 110, 36-43. https://doi.org/10.1016/j.tube.2018.02.009

Farhat, M. R., Freschi, L., Calderon, R., Ioerger, T., Snyder, M., Meehan, C. J., de Jong, B., Rigouts, L., Sloutsky, A., Kaur, D., Sunyaev, S., van Soolingen, D., Shendure, J., Sacchettini, J., \& Murray, M. (2019). GWAS for quantitative resistance phenotypes in Mycobacterium tuberculosis reveals resistance genes and regulatory regions. Nature Communications, 10(1), 2128. https://doi.org/10.1038/s41467-019-10110-6

García, D. F., \& Astudillo, M. (2019). Genotipificación de aislamientos del complejo Mycobacterium tuberculosis mediante MIRU-VNTR, Cali, Colombia, 20132015. Biomédica, 39(1), 71-85. https://doi.org/10.7705/biomedica.v39i2.3924

Garzon-Chavez, D., Garcia-Bereguiain, M. A., Mora-Pinargote, C., Granda-Pardo, J. C., Leon-Benitez, M., Franco-Sotomayor, G., Trueba, G., \& de Waard, J. H. (2020). Population structure and genetic diversity of Mycobacterium tuberculosis in Ecuador. Scientific Reports, 10(6237), Article 1. https://doi.org/10.1038/s41598020-62824-z

Garzon-Chavez, D., Zurita, J., Mora-Pinargote, C., Franco-Sotomayor, G., Leon-Benitez, M., Granda-Pardo, J. C., Trueba, G., Garcia-Bereguiain, M. A., \& de Waard, J. H. (2019). Prevalence, Drug Resistance, and Genotypic Diversity of the Mycobacterium tuberculosis Beijing Family in Ecuador. Microbial Drug Resistance (Larchmont, N.Y.), 25(6), 931-937. https://doi.org/10.1089/mdr.2018.0429 
Gomes, H. M., Elias, A. R., Oelemann, M. A. C., Pereira, M. A. da S., Montes, F. F. O., Marsico, A. G., Kritski, A. L., Filho, L. dos A., Caldas, P. C., Possuelo, L. G., Cafrune, P., Rossetti, M. L., Lucena, N., Saad, M. H. F., Cavalcanti, H. R., Leite, C. Q. F., de Brito, R. C., Lopes, M. L., Lima, K., ... Suffys, P. N. (2012). Spoligotypes of Mycobacterium tuberculosis complex isolates from patients residents of 11 states of Brazil. Infection, Genetics and Evolution: Journal of Molecular Epidemiology and Evolutionary Genetics in Infectious Diseases, 12(4), 649-656. https://doi.org/10.1016/j.meegid.2011.08.027

Grandjean, L., Gilman, R. H., Iwamoto, T., Köser, C. U., Coronel, J., Zimic, M., Török, M. E., Ayabina, D., Kendall, M., Fraser, C., Harris, S., Parkhill, J., Peacock, S. J., Moore, D. A. J., \& Colijn, C. (2017). Convergent evolution and topologically disruptive polymorphisms among multidrug-resistant tuberculosis in Peru. PLOS ONE, 12(12), e0189838. https://doi.org/10.1371/journal.pone.0189838

Grandjean, L., Iwamoto, T., Lithgow, A., Gilman, R. H., Arikawa, K., Nakanishi, N., Martin, L., Castillo, E., Alarcon, V., Coronel, J., Solano, W., Aminian, M., Guezala, C., Rastogi, N., Couvin, D., Sheen, P., Zimic, M., \& Moore, D. A. (2015). The Association between Mycobacterium Tuberculosis Genotype and Drug Resistance in Peru. PLOS ONE, 10(5), e0126271. https://doi.org/10.1371/journal.pone.0126271

Guernier, V., Sola, C., Brudey, K., Guégan, J.-F., \& Rastogi, N. (2008). Use of clustergraphs from spoligotyping data to study genotype similarities and a comparison of three indices to quantify recent tuberculosis transmission among culture positive cases in French Guiana during a eight year period. BMC Infectious Diseases, 8. https://doi.org/10.1186/1471-2334-8-46

Guerra, J., Mogollón, D., González, D., Sanchez, R., Rueda, Z. V., Parra-López, C. A., \& Murcia, M. I. (2019). Active and latent tuberculosis among inmates in La Esperanza prison in Guaduas, Colombia. PLOS ONE, 14(1), e0209895. https://doi.org/10.1371/journal.pone.0209895

Guthrie, J. L., Strudwick, L., Roberts, B., Allen, M., McFadzen, J., Roth, D., Jorgensen, D., Rodrigues, M., Tang, P., Hanley, B., Johnston, J., Cook, V. J., \& Gardy, J. L. (2019). Whole genome sequencing for improved understanding of Mycobacterium tuberculosis transmission in a remote circumpolar region. Epidemiology and Infection, $147, \quad \mathrm{e} 188$. https://doi.org/10.1017/S0950268819000670

Hill, J., Dickson-Hall, L., Grant, A. D., Grundy, C., Black, J., Kielmann, K., Mlisana, K., Mitrani, L., Loveday, M., Moshabela, M., Le Roux, S., Jassat, W., Nicol, M., \& Cox, H. (2020). Drug-resistant tuberculosis patient care journeys in South Africa: A pilot study using routine laboratory data. The International Journal of Tuberculosis and Lung Disease: The Official Journal of the International Union 
Against Tuberculosis and Lung Disease, 24(1), 83-91. https://doi.org/10.5588/ijtld.19.0100

Homolka, S., Paulowski, L., Andres, S., Hillemann, D., Jou, R., Günther, G., Claassens, M., Kuhns, M., Niemann, S., \& Maurer, F. P. (2020). Two Pandemics, One Challenge-Leveraging Molecular Test Capacity of Tuberculosis Laboratories for Rapid COVID-19 Case-Finding-Volume 26, Number 11-November 2020Emerging Infectious Diseases journal-CDC. 26(11). https://doi.org/10.3201/eid2611.202602

Huang, C.-C., Chu, A. L., Becerra, M. C., Galea, J. T., Calderón, R., Contreras, C., Yataco, R., Zhang, Z., Lecca, L., \& Murray, M. B. (2020). Mycobacterium tuberculosis Beijing Lineage and Risk for Tuberculosis in Child Household Contacts, Peru. Emerging Infectious Diseases, 26(3), 568-578. https://doi.org/10.3201/eid2603.191314

Imperiale, B. R., Zumárraga, M. J., Di Giulio, A. B., Cataldi, A. A., \& Morcillo, N. S. (2013). Molecular and phenotypic characterisation of Mycobacterium tuberculosis resistant to anti-tuberculosis drugs. The International Journal of Tuberculosis and Lung Disease: The Official Journal of the International Union Against Tuberculosis and Lung Disease, 17(8), 1088-1093. https://doi.org/10.5588/ijtld.12.0949

Imperiale, Belén Rocío, Di Giulio, Á. B., Mancino, M. B., Zumárraga, M. J., \& Morcillo, N. S. (2019). Surveillance and characterization of drug-resistant Mycobacterium tuberculosis isolated in a reference hospital from Argentina during 8 years' period. International Journal of Mycobacteriology, 8(3), 223-228. https://doi.org/10.4103/ijmy.ijmy_94_19

Instituto Nacional de Salud de Colombia. (2020). Boletín epidemiológico semanal. Semana $12 \quad$ (N. $\left.{ }^{\circ} \quad 12\right)$. https://www.ins.gov.co/buscadoreventos/BoletinEpidemiologico/2020_Boletin_epidemiologico_semana_12.pdf

Jiménez, P., Calvopiña, K., Herrera, D., Rojas, C., Pérez-Lago, L., Grijalva, M., Guna, R., \& Viedma, D. G. (2017). Identification of the Mycobacterium tuberculosis Beijing lineage in Ecuador. Biomédica, 37(2), 233-237. https://doi.org/10.7705/biomedica.v37i3.3450

Lagos, J., Couvin, D., Arata, L., Tognarelli, J., Aguayo, C., Leiva, T., Arias, F., Hormazabal, J. C., Rastogi, N., \& Fernández, J. (2016). Analysis of Mycobacterium tuberculosis Genotypic Lineage Distribution in Chile and Neighboring Countries. PLOS ONE, 11(8), e0160434. https://doi.org/10.1371/journal.pone.0160434

Lazzarini, L. C. O., Huard, R. C., Boechat, N. L., Gomes, H. M., Oelemann, M. C., Kurepina, N., Shashkina, E., Mello, F. C. Q., Gibson, A. L., Virginio, M. J., 
Marsico, A. G., Butler, W. R., Kreiswirth, B. N., Suffys, P. N., Lapa e Silva, J. R., \& Ho, J. L. (2007). Discovery of a Novel Mycobacterium tuberculosis Lineage That Is a Major Cause of Tuberculosis in Rio de Janeiro, Brazil. Journal of Clinical Microbiology, 45(12), 3891-3902. https://doi.org/10.1128/JCM.0139407

Luiz, R. D. S. S., Suffys, P., Barroso, E. C., Kerr, L. R. F. S., Duarte, C. R., Freitas, M. V. C., Mota, R. M. S., \& Frota, C. C. (2013). Genotyping and drug resistance patterns of Mycobacterium tuberculosis strains observed in a tuberculosis highburden municipality in Northeast, Brazil. The Brazilian Journal of Infectious Diseases: An Official Publication of the Brazilian Society of Infectious Diseases, 17(3), 338-345. https://doi.org/10.1016/j.bjid.2012.10.019

Machado, L. N. C., Marcondes, N. R., Leite, C. Q. F., Santos, A. C. B., Pavan, F. R., Baldin, V. P., Castilho, A. L., Siqueira, V. L. D., Baeza, L. C., Berghs, H., \& Cardoso, R. F. (2014). First Baseline of Circulating Genotypic Lineages of Mycobacterium tuberculosis in Patients from the Brazilian Borders with Argentina and Paraguay. PLOS ONE, 9(9), e107106. https://doi.org/10.1371/journal.pone.0107106

Maes, M., Kremer, K., van Soolingen, D., Takiff, H., \& de Waard, J. H. (2008). 24-locus MIRU-VNTR genotyping is a useful tool to study the molecular epidemiology of tuberculosis among Warao Amerindians in Venezuela. Tuberculosis (Edinburgh, Scotland), 88(5), 490-494. https://doi.org/10.1016/j.tube.2008.04.003

Martins, M. C., Giampaglia, C. M. S., Oliveira, R. S., Simonsen, V., Latrilha, F. O., Moniz, L. L., Couvin, D., Rastogi, N., \& Ferrazoli, L. (2013). Population structure and circulating genotypes of drug-sensitive and drug-resistant Mycobacterium tuberculosis clinical isolates in São Paulo state, Brazil. Infection, Genetics and Evolution, 14, 39-45. https://doi.org/10.1016/j.meegid.2012.10.015

McQuaid, C. F., McCreesh, N., Read, J. M., Sumner, T., CMMID COVID-19 Working Group, Houben, R. M. G. J., White, R. G., \& Harris, R. C. (2020). The potential impact of COVID-19-related disruption on tuberculosis burden. European Respiratory Journal, 56(2), 2001718. https://doi.org/10.1183/13993003.017182020

Medeiros, T. F., Nogueira, C. L., Prim, R. I., Scheffer, M. C., Alves, E. V., Rovaris, D. B., Zozio, T., Rastogi, N., \& Bazzo, M. L. (2018). Molecular epidemiology of Mycobacterium tuberculosis strains from prison populations in Santa Catarina, Southern Brazil. Infection, Genetics and Evolution: Journal of Molecular Epidemiology and Evolutionary Genetics in Infectious Diseases, 58, 34-39. https://doi.org/10.1016/j.meegid.2017.12.010 
Meehan, C. J., Goig, G. A., Kohl, T. A., Verboven, L., Dippenaar, A., Ezewudo, M., Farhat, M. R., Guthrie, J. L., Laukens, K., Miotto, P., Ofori-Anyinam, B., Dreyer, V., Supply, P., Suresh, A., Utpatel, C., van Soolingen, D., Zhou, Y., Ashton, P. M., Brites, D., ... Van Rie, A. (2019). Whole genome sequencing of Mycobacterium tuberculosis: Current standards and open issues. Nature Reviews Microbiology, 17(9), 533-545. https://doi.org/10.1038/s41579-019-0214-5

Meza, P., Balcells, M. E., Miranda, C., Cifuentes, M., Wozniak, A., \& García, P. (2014). Presence of Bejing genotype among Mycobacterium tuberculosis strains in two centres of the Region Metropolitana of Chile. Revista chilena de infectología, 31(1), 21-27. https://doi.org/10.4067/S0716-10182014000100003

Millet, J., Baboolal, S., Streit, E., Akpaka, P. E., \& Rastogi, N. (2014). A First Assessment of Mycobacterium tuberculosis Genetic Diversity and Drug-Resistance Patterns in Twelve Caribbean Territories. BioMed Research International, 2014, e718496. https://doi.org/10.1155/2014/718496

Ministerio de Salud. (2018). Informe de situación epidemiológica y operacional del Programa Nacional de Tuberculosis 2017.. Chile.

Ministerio de Salud Argentina. (2020). Boletín sobre Tuberculosis en la Argentina N3. https://bancos.salud.gob.ar/sites/default/files/2020-10/boletin-epidemiologicotb-2020.pdf

Ministerio de Salud Pública, Secretaría de Vigilancia de la Salud Pública, \& Dirección Nacional de Vigilancia Epidemiológica. (2019). Boletín Anual Tuberculosis 2018. Ecuador.

Ministerio de Salud Pública y Bienestar Social. (2019). Tuberculosis: Enfermedad respiratoria mortal que tiene cura. Paraguay.

Monteserin, J., Camacho, M., Barrera, L., Palomino, J. C., Ritacco, V., \& Martin, A. (2013). Genotypes of Mycobacterium tuberculosis in patients at risk of drug resistance in Bolivia. Infection, Genetics and Evolution: Journal of Molecular Epidemiology and Evolutionary Genetics in Infectious Diseases, 17, 195-201. https://doi.org/10.1016/j.meegid.2013.04.010

Monteserin, J., Paul, R., Gravina, E., Reniero, A., Hernandez, T., Mazzeo, E., Togneri, A., Simboli, N., López, B., Couvin, D., Rastogi, N., \& Ritacco, V. (2018). Genotypic diversity of Mycobacterium tuberculosis in Buenos Aires, Argentina. Infection, Genetics and Evolution: Journal of Molecular Epidemiology and Evolutionary Genetics in Infectious Diseases, 62, 1-7. https://doi.org/10.1016/j.meegid.2018.04.006

Moraes, E. B., Slompo, L., Finardi, A. J., Silveira, H. P. P. da, Ruiz, L., Gomes, H. M., Richini, V. B., Suffys, P., Fortaleza, C. M. C. B., Cavalcanti, R., Baptista, I. M. 
F. D., Moraes, E. B., Slompo, L., Finardi, A. J., Silveira, H. P. P. da, Ruiz, L., Gomes, H. M., Richini, V. B., Suffys, P., ... Baptista, I. M. F. D. (2017). Tuberculosis associated factors caused by Mycobacterium tuberculosis of the RDRio genotype. Memórias Do Instituto Oswaldo Cruz, 112(3), 182-187. https://doi.org/10.1590/0074-02760160347

Motta, I., Centis, R., D’Ambrosio, L., García-García, J.-M., Goletti, D., Gualano, G., Lipani, F., Palmieri, F., Sánchez-Montalvá, A., Pontali, E., Sotgiu, G., Spanevello, A., Stochino, C., Tabernero, E., Tadolini, M., van den Boom, M., Villa, S., Visca, D., \& Migliori, G. B. (2020). Tuberculosis, COVID-19 and migrants: Preliminary analysis of deaths occurring in 69 patients from two cohorts. Pulmonology, 26(4), 233-240. https://doi.org/10.1016/j.pulmoe.2020.05.002

Nacher, M., Adenis, A., Abboud, P., Djossou, F., Demar, M., Epelboin, L., \& Couppié, P. (2020). HIV patients dying on anti-tuberculosis treatment: Are undiagnosed infections still a problem in French Guiana? BMC Research Notes, 13(209). https://doi.org/10.1186/s13104-020-05054-w

Nogueira, C. L., Prim, R. I., Senna, S. G., Rovaris, D. B., Maurici, R., Rossetti, M. L., Couvin, D., Rastogi, N., \& Bazzo, M. L. (2016). First insight into the molecular epidemiology of Mycobacterium tuberculosis in Santa Catarina, southern Brazil.

$\begin{array}{llll}\text { Tuberculosis } \quad \text { (Edinburgh, } & \text { Scotland), } & \text { 97, } & \text { 57-64. }\end{array}$ https://doi.org/10.1016/j.tube.2015.12.005

Noguti, E. N., Leite, C. Q. F., Malaspina, A. C., Santos, A. C. B., Hirata, R. D. C., Hirata, M. H., Mamizuka, E. M., \& Cardoso, R. F. (2010). Genotyping of Mycobacterium tuberculosis isolates from alow-endemic setting in northwestern state of Paraná in Southern Brazil. Memórias do Instituto Oswaldo Cruz, 105(6), 779-785. https://doi.org/10.1590/S0074-02762010000600008

PAHO. (2018). Tuberculosis in the Americas, 2018. http://iris.paho.org/xmlui/handle/10665.2/49510

PAHO. (2020). Tuberculosis in the Americas. Regional Report 2019 (License: CC BYNC-SA 3.0 IGO).

PAHO/WHO. (2019a, marzo 25). OPS/OMS Bolivia-La suma de acciones pueden poner fin a la tuberculosis. Pan American Health Organization / World Health Organization.

https://www.paho.org/bol/index.php?option=com_content $\&$ view=article\&id=22 25:la-suma-de-acciones-pueden-poner-fin-a-la-tuberculosis\&Itemid=481

PAHO/WHO. (2019b, marzo 26). PAHO/WHO Guyana -Día Mundial de la Tuberculosis 2019. Pan American Health Organization / World Health Organization. https://www.paho.org/guy/index.php?option=com_content \&view=article\&id=35 3: world-tb-day-2019\&Itemid=0 
Puerto, D., Erazo, L., Zabaleta, A., Murcia, M. I., Llerena, C., Puerto, G., Puerto, D., Erazo, L., Zabaleta, A., Murcia, M. I., Llerena, C., \& Puerto, G. (2019). Characterization of clinical isolates of Mycobacterium tuberculosis from indigenous peoples of Colombia. Biomédica, 39, 78-92. https://doi.org/10.7705/biomedica.v39i3.4318

Puerto, G., Erazo, L., Wintaco, M., Castro, C., Ribón, W., \& Guerrero, M. I. (2015). Mycobacterium tuberculosis Genotypes Determined by Spoligotyping to Be Circulating in Colombia between 1999 and 2012 and Their Possible Associations with Transmission and Susceptibility to First-Line Drugs. PLoS ONE, 10(6), e0124308. https://doi.org/10.1371/journal.pone.0124308

Realpe, T., Correa, N., Rozo, J. C., Ferro, B. E., Gomez, V., Zapata, E., Ribon, W., Puerto, G., Castro, C., Nieto, L. M., Diaz, M. L., Rivera, O., Couvin, D., Rastogi, N., Arbelaez, M. P., \& Robledo, J. (2014). Population Structure among Mycobacterium tuberculosis Isolates from Pulmonary Tuberculosis Patients in $\begin{array}{llll}\text { Colombia. } & \text { PLOS } & \text { ONE, } & \text { e93848. }\end{array}$ https://doi.org/10.1371/journal.pone.0093848

Rodrigues, N. C. P., Andrade, M. K. de N., O’Dwyer, G., Flynn, M., Braga, J. U., Almeida, A. S. de, Bastos, L. S., Lino, V. T. S., Rodrigues, N. C. P., Andrade, M. K. de N., O’Dwyer, G., Flynn, M., Braga, J. U., Almeida, A. S. de, Bastos, L. S., \& Lino, V. T. S. (2017). Distribution of pulmonary tuberculosis in Rio de Janeiro (Brazil): A spatial analysis. Ciência \&amp; Saúde Coletiva, 22(12), 4125-4134. https://doi.org/10.1590/1413-812320172212.0143016

Salvato, R. S., Schiefelbein, S., Barcellos, R. B., Praetzel, B. M., Anusca, I. S., Esteves, L. S., Halon, M. L., Unis, G., Dias, C. F., Miranda, S. S., de Almeida, I. N., de Assis Figueredo, L. J., Silva, E. C., Kritski, A. L., Dalla Costa, E. R., \& Rossetti, M. L. R. (2019). Molecular characterisation of multidrug-resistant Mycobacterium tuberculosis isolates from a high-burden tuberculosis state in Brazil. Epidemiology and Infection, 147, e216. https://doi.org/10.1017/S0950268819001006

Sheen, P., Couvin, D., Grandjean, L., Zimic, M., Dominguez, M., Luna, G., Gilman, R. H., Rastogi, N., \& Moore, D. A. J. (2013). Genetic diversity of Mycobacterium tuberculosis in Peru and exploration of phylogenetic associations with drug resistance. PloS One, 8(6), e65873. https://doi.org/10.1371/journal.pone.0065873

Soares, R. O., Macedo, M. B. de, von Groll, A., \& Silva, P. E. A. da. (2013). Mycobacterium tuberculosis belonging to family LAM and sublineage RD Rio: Common strains in Southern Brazil for over 10 years. Brazilian Journal of Microbiology, 44(4), 1251-1255. https://doi.org/10.1590/S151783822013000400032 
Soto Cabezas, M. G., Munayco Escate, C. V., Escalante Maldonado, O., Valencia Torres, E., Arica Gutiérrez, J., \& Yagui Moscoso, M. J. A. (2020). Perfil epidemiológico de la tuberculosis extensivamente resistente en el Perú, 2013-2015. Revista Panamericana de Salud Pública, 44. https://doi.org/10.26633/RPSP.2020.29

Streit, E., Baboolal, S., Akpaka, P., Millet, J., \& Rastogi, N. (2014). Finer characterization of Mycobacterium tuberculosis using spoligotyping 4 and 15-loci MIRU-VNTRs reveals phylogeographical specificities of 5 isolates circulating in Guyana and Suriname. Infection, Genetics and Evolution, 30, 114-119. https://doi.org/10.1016/j.meegid.2014.12.015

Taype, C. A., Agapito, J. C., Accinelli, R. A., Espinoza, J. R., Godreuil, S., Goodman, S. J., Bañuls, A. L., \& Shaw, M. A. (2012). Genetic diversity, population structure and drug resistance of Mycobacterium tuberculosis in Peru. Infection, Genetics and Evolution, 12(3), 577-585. https://doi.org/10.1016/j.meegid.2012.02.002

Vasconcellos, S. E. G., Acosta, C. C., Gomes, L. L., Conceição, E. C., Lima, K. V., de Araujo, M. I., Leite, M. de L., Tannure, F., Caldas, P. C. de S., Gomes, H. M., Santos, A. R., Gomgnimbou, M. K., Sola, C., Couvin, D., Rastogi, N., Boechat, N., \& Suffys, P. N. (2014). Strain classification of Mycobacterium tuberculosis isolates in Brazil based on genotypes obtained by spoligotyping, mycobacterial interspersed repetitive unit typing and the presence of large sequence and single nucleotide polymorphism. PloS One, 9(10), e107747. https://doi.org/10.1371/journal.pone.0107747

World Health Organization. (2020). Global tuberculosis report 2020.

Zhang, Y., Liu, M., Wu, S. S., Jiang, H., Zhang, J., Wang, S., Ma, W., Li, Q., Ma, Y., Liu, Y., Feng, W., Amsalu, E., Li, X., Wang, W., Li, W., \& Guo, X. (2019). Spatial distribution of tuberculosis and its association with meteorological factors in mainland China. BMC Infectious Diseases, 19(379). https://doi.org/10.1186/s12879-019-4008-1

Zurita, J., Espinel, N., Barba, P., Ortega-Paredes, D., Zurita-Salinas, C., Rojas, Y., \& Alcocer, I. (2019). Genetic diversity and drug resistance of Mycobacterium tuberculosis in Ecuador. The International Journal of Tuberculosis and Lung Disease: The Official Journal of the International Union Against Tuberculosis and Lung Disease, 23(2), 166-173. https://doi.org/10.5588/ijtld.18.0095

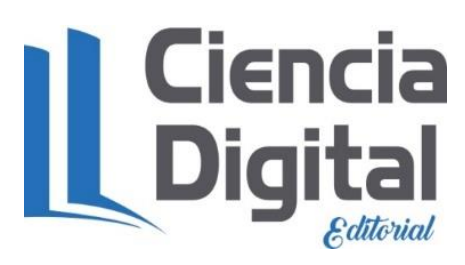




\section{PARA CITAR EL ARTÍCULO INDEXADO.}

Cabezas Vinueza, L., \& Jiménez Arias, P. (2021). Distribution of Mycobacterium tuberculosis lineages in South America. Anatomía Digital, 4(3), 34-58. https://doi.org/10.33262/anatomiadigital.v4i3.1755

\section{\Ciencia}

El artículo que se publica es de exclusiva responsabilidad de los autores y no necesariamente reflejan el pensamiento de la Revista Anatomía Digital.

El artículo queda en propiedad de la revista y, por tanto, su publicación parcial y/o total en otro medio tiene que ser autorizado por el director de la Revista Anatomía Digital.
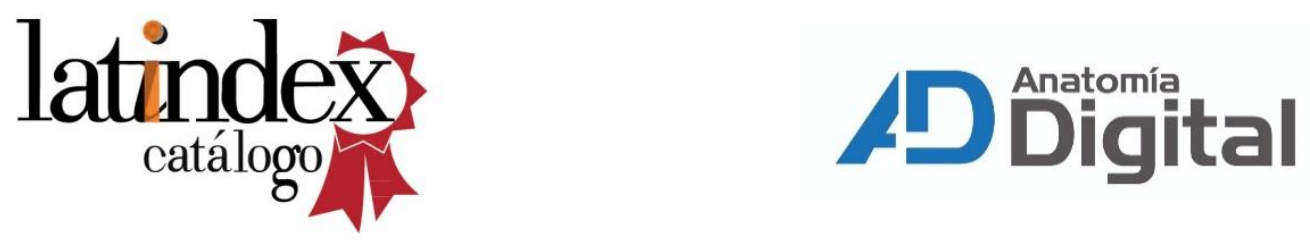